\title{
The small heat shock protein $\alpha$ A-crystallin negatively regulates pancreatic tumorigenesis
}

\author{
Jifang Liu ${ }^{1,3, *}$, Zhongwen Luo ${ }^{1, *}$, Lan Zhang ${ }^{1, *}$, Ling Wang ${ }^{1,2,4, *}$, Qian Nie ${ }^{1,4, *}$, Zheng- \\ Feng Wang ${ }^{2,5, *}$, Zhaoxia Huang ${ }^{2,4}$, Xiaohui Hu ${ }^{2,4}$, Lili Gong ${ }^{1}$, Andre-Patrick Arrigo ${ }^{1}$, \\ Xiangcheng Tang ${ }^{1}$, Jia-Wen Xiang ${ }^{4}$, Fangyuan Liu ${ }^{1}$, Mi Deng ${ }^{2}$, Weike $\mathrm{Ji}^{2}$, Wenfeng \\ $\mathrm{Hu}^{2}$, Ji-Ye Zhu ${ }^{5}$, Baojiang Chen ${ }^{6}$, Julia Bridge ${ }^{7}$, Michael A. Hollingsworth ${ }^{8}$, James \\ Gigantelli², Yizhi Liu ${ }^{1}$, Quan D. Nguyen ${ }^{2}$, David Wan-Cheng Li ${ }^{1,2,4,8}$

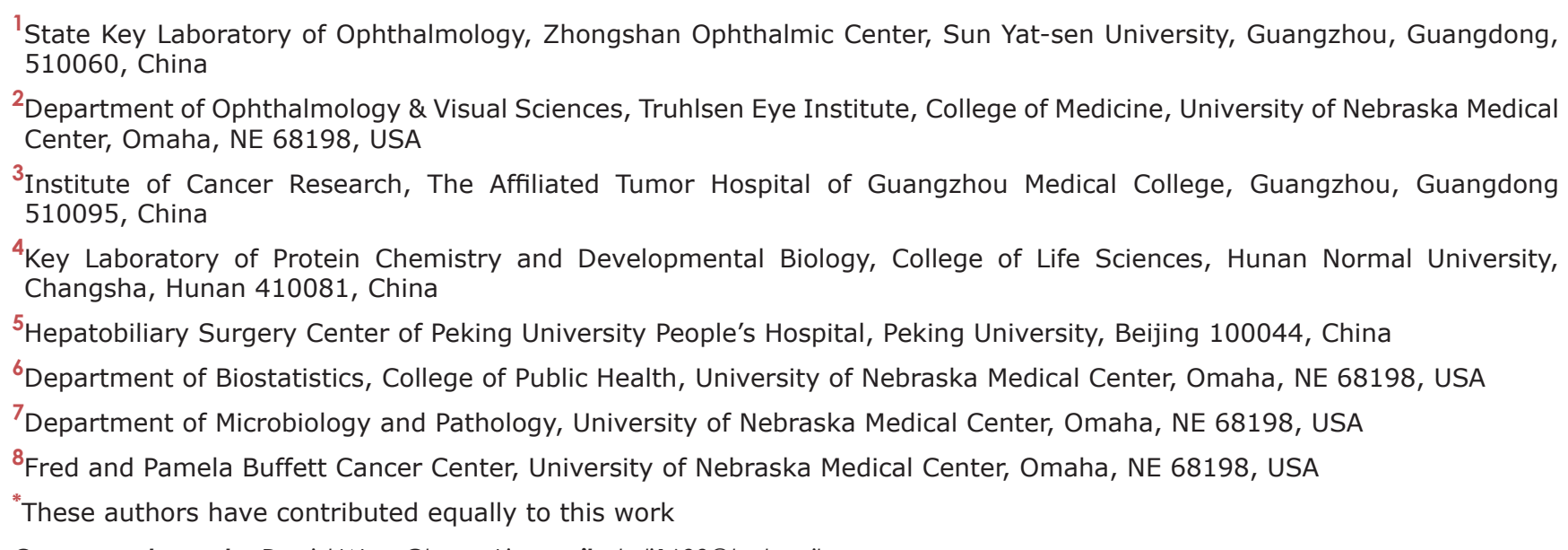

Correspondence to: David Wan-Cheng Li, email: dwli1688@hotmail.com

Keywords: small heat shock protein, $\alpha \mathrm{A}$, pancreatic cancer, tumor suppression, cancer therapy

Received: June 01,2016 Accepted: August 14, $2016 \quad$ Published: August 29, 2016

\section{ABSTRACT}

Our recent study has shown that $\alpha A$-crystallin appears to act as a tumor suppressor in pancreas. Here, we analyzed expression patterns of $\alpha A$-crystallin in the pancreatic tumor tissue and the neighbor normal tissue from 74 pancreatic cancer patients and also pancreatic cancer cell lines. Immunocytochemistry revealed that $\alpha A$-crystallin was highly expressed in the normal tissue from 56 patients, but barely detectable in the pancreatic tumor tissue. Moreover, a low level of $\alpha A-$ crystallin predicts poor prognosis for patients with pancreatic duct adenocarcinoma (PDAC). In the 12 pancreatic cell lines analyzed, except for Capan-1 and Miapaca-2 where the level of $\alpha A$-crystallin was about $80 \%$ and $65 \%$ of that in the control cell line, HPNE, the remaining pancreatic cancer cells have much lower $\alpha A$-crystallin levels. Overexpression of $\alpha \mathrm{A}$-crystallin in MiaPaca-1 cells lacking endogenous $\alpha \mathrm{A}-$ crystallin significantly decreased its tumorigenicity ability as shown in the colony formation and wound healing assays. In contrast, knockdown of $\alpha A$-crystallin in the Capan-1 cells significantly increased its tumorigenicity ability as demonstrated in the above assays. Together, our results further demonstrate that $\alpha A$-crystallin negatively regulates pancreatic tumorigenesis and appears to be a prognosis biomarker for PDAC. 


\section{INTRODUCTION}

Pancreatic cancer, the fourth leading cause of cancer related death in the United States among both men and women [1] is one of the few malignancies with high mortality and short median survival period [2]. The high mortality is derived from the fact that most patients are present with metastatic or locally advanced diseases at the time of diagnosis. In addition, the pancreatic cancer cells are resistant to conventional chemotherapy and radiotherapy [3-6].

At the molecular level, pancreatic malignancies are progressed from non-neoplastic cells to invasive adenocarcinoma through a series of pre-malignant lesions characterized by progressively increasing dysplasia. These precursors are named as pancreatic intraepithelial neoplasia (PanINs) with well-characterized stages including PanIN-1a-flat, PanIN-1b-papillary without dysplasia, PanIn-2-papillary with dysplasia, and PanIN3-carcinoma-in situ [4]. Development of pancreatic malignancies is resulted from orchestrated actions of canonical oncogenes and tumor suppressor genes, such as Ki-Ras, p16, p53, Smad4 and BRCA2. The functions of these genes are regulated by various cellular signaling pathways including TGF $\beta /$ SMAD, PI3K/AKT, and MAPK pathways [7-17].

$\alpha \mathrm{A}$-crystallin is a member of the small heat-shock protein family (sHSPs) with multiple functions. Small HSPs act as molecular chaperones, and participate in signaling transduction, cell proliferation, cell metabolism, cell survival, apoptosis, senescence, exocytosis and endocytosis [18-22]. Studies from numerous laboratories including ours have revealed that sHSPs also actively regulate tumorigenesis [23-26]. As a major lens structural protein, $\alpha \mathrm{A}$-crystallin is also expressed in nonlenticular tissues including retina, spleen and thymus [27]. Our recent study demonstrated that $\alpha \mathrm{A}$-crystallin is significantly expressed in mouse pancreas [28]. Moreover, analysis of $\alpha \mathrm{A}$-crystallin in the tissue array samples from normal human pancreas and dozens of cases of pancreatic carcinoma reveals significant difference. $\alpha$ A-crystallin is decreased over 10 -fold in the pancreatic carcinoma of various types than that in normal pancreas, suggesting that $\alpha \mathrm{A}$-crystallin has tumor suppression functions. Moreover, $\alpha \mathrm{A}$-crystallin negatively regulates cell migration as shown in the pancreatic cancer cell wound healing assay [28].

To further examine if $\alpha \mathrm{A}$-crystallin expression is linked to inhibition of pancreatic cancer development, we have analyzed the expression levels of $\alpha \mathrm{A}$-crystallin in the pancreatic tumor tissue verse the neighboring normal tissues from 74 patients and found that in 56 of 74 patients, expression of $\alpha \mathrm{A}$-crystallin was significantly decreased in the tumor tissue than that in the neighbor tissue. Moreover, we have also examined the expression level of aA-crystallin in various pancreatic cancer cell lines and further tested the role of $\alpha \mathrm{A}$-crystallin in inhibiting cancer development in these cells. Our data show that expression of $\alpha \mathrm{A}$-crystallin is significantly lower in majority of pancreatic cancer cell lines compared with the nestin-expressing normal pancreatic cancer cells (HPNE cells) [29]. When $\alpha \mathrm{A}$-crystallin is knocked down in the pancreatic cells expressing moderate $\alpha \mathrm{A}$-crystallin, the transformation and cell migration abilities are clearly increased. In contrast, when $\alpha \mathrm{A}$-crystallin is expressed in those pancreatic cancer cells lacking endogenous $\alpha \mathrm{A}$ crystallin, the transformation and cell migration abilities of the transgenic cells became significantly decreased. Together, our results support the conclusion that $\alpha \mathrm{A}$ crystallin negatively regulates pancreatic tumorigenesis and decreased expression of $\alpha \mathrm{A}$-crystallin independently predicts poor prognosis of pancreatic cancer.

\section{RESULTS}

\section{$\alpha A$-crystallin expression patterns in tissue samples from pancreatic cancer patients}

To further determine the relationship between expression of the $\alpha \mathrm{A}$-crystallin and development of pancreatic cancer, we analyzed the expression patterns of $\alpha \mathrm{A}$-crystallin in 74 paired pancreatic cancer tissues and adjacent non-tumor tissues using immunohistochemistry analysis. As shown in Figure 1, $\alpha$ A-crystallin was localized in the cytoplasm of pancreatic epithelial cells of the para-tumor tissue but hardly detectable in the tumor cells. Quantitation of the positive signals demonstrated that 56/74 (75.7\%) adjacent non-tumor tissues displayed strong $\alpha \mathrm{A}$-crystallin expression. In contrast, only 21 of $74(28.4 \%)$ patients exhibited some overexpression of $\alpha \mathrm{A}$-crystallin (scored as $<3$ ) in both pancreatic cancer tissues and the adjacent non-tumor tissues. Therefore, $\alpha \mathrm{A}$-crystallin seems to be dramatically decreased during pancreatic carcinogenesis.

\section{Relationship between $\alpha A$-crystallin expression and clinical outcome of patients}

Next, we analyzed the correlation between $\alpha \mathrm{A}$ crystallin expression with clinicopathologic factors of patients with PDAC including gender, age, tumor size, differentiation, $\mathrm{pT}$ classification, lymph node metastasis and neural infiltration. As shown in Table 1, a decreased $\alpha \mathrm{A}$-crystallin expression was significantly correlated with pT classification and lymph node metastasis $(\mathrm{P}=0.019$ and $\mathrm{P}=0.004$, respectively), but not with other clinical or pathologic factors. To track the correlation between levels of $\alpha \mathrm{A}$-crystallin and the overall survival (OS) of patents, we followed the patients for 5 years. Survival analysis by the Kaplan-Meier method indicated that OS $(\mathrm{P}=0.011)$ was significantly worse among patients with $\alpha$ A crystallinlow group (Figure 2). Patients in $\alpha \mathrm{A}$-crystallin-low group had less median OS (18 vs 48 months) than those in $\alpha \mathrm{A}$ - 


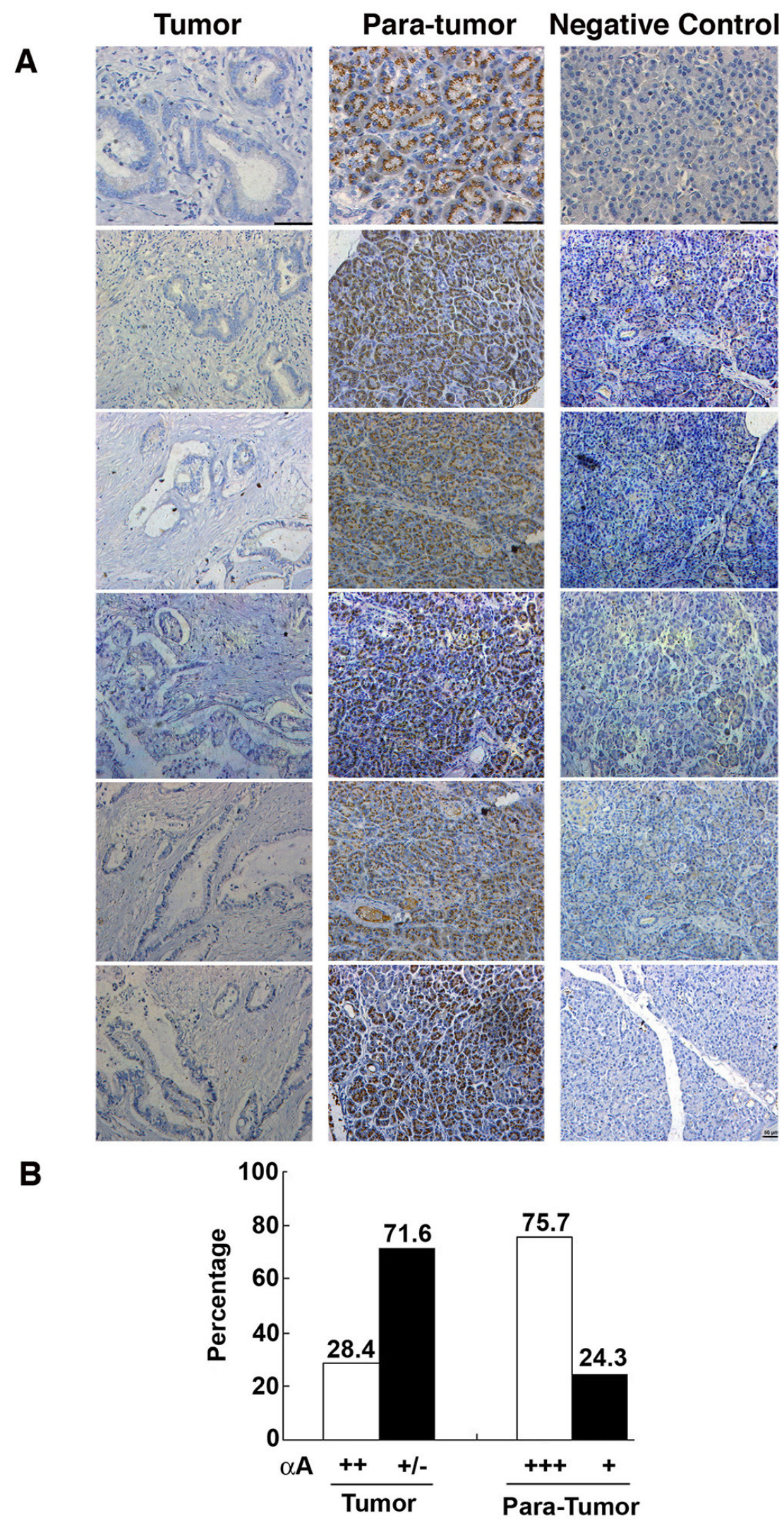

Figure 1: Contrast expression patterns of $\alpha \mathrm{A}$-crystallin in pancreatic cancer tissues and para-tumor tissues. A. Representative images of immunohistochemical (IHC) assays of $\alpha$ A-crystallin in paired pancreatic tumors and para-tumor tissues. Scar bars, $50 \mu \mathrm{m}$. B. Quantitation of high or low levels of $\alpha \mathrm{A}$-crystallin expression in pancreatic cancer samples and para-tumor tissues. 
Table 1: Associations of $\alpha$ A-Crystallin Expression with Clinicopathological Parameters in 74 PDAC Patients

\begin{tabular}{|c|c|c|c|c|}
\hline \multirow{2}{*}{ Characteristics } & \multirow{2}{*}{$\mathbf{n}$} & \multicolumn{2}{|c|}{$\alpha A-C r y s t a l l i n$ Expression } & \multirow[b]{2}{*}{$p$-valuc } \\
\hline & & High & Low & \\
\hline \multicolumn{5}{|l|}{ Gender } \\
\hline Male & 51 & 12 & 39 & 0.178 \\
\hline Female & 23 & 9 & 14 & \\
\hline Age (Years) & & & & 0.282 \\
\hline$\leq 65$ & 48 & 15 & 33 & \\
\hline$>65$ & 26 & 5 & 21 & \\
\hline \multicolumn{5}{|l|}{ Tumor Size (cm) } \\
\hline$\leq 5$ & 55 & 17 & 38 & 0.558 \\
\hline$>5$ & 19 & 4 & 15 & \\
\hline Differentiation & & & & 0.578 \\
\hline Well/Moderate & 23 & 5 & 18 & \\
\hline Poor & 51 & 16 & 35 & \\
\hline PT Classification & & & & 0.019 \\
\hline pT1 & 6 & 4 & 2 & \\
\hline pT2 & 53 & 16 & 37 & \\
\hline pT3 & 15 & 1 & 14 & \\
\hline \multicolumn{5}{|l|}{ Lymph Node } \\
\hline pNo & 31 & 11 & 20 & 0.004 \\
\hline pN1 & 43 & 5 & 33 & \\
\hline \multicolumn{5}{|l|}{ Neural Infiltration } \\
\hline Yes & 38 & 9 & 29 & 0.442 \\
\hline No & 36 & 12 & 24 & \\
\hline
\end{tabular}

P-values were two-tailed and based on the Pearson chi-square test. $P<0.05$ are statistically significant.

crystallin-high group. Thus, a low level of $\alpha \mathrm{A}$-crystallin expression was found associated with a poor prognosis of patients with PDAC.

Furthermore, multivariate analysis revealed that tumor size, differentiation, pT classification, lymph node metastasis and neural infiltration were unfavorable predictors for OS of PDAC patients, but $\alpha \mathrm{A}$-crystallin was associated with OS (Table 2). Together, a low $\alpha \mathrm{A}$ crystallin level may be used independently to predict poor prognosis for patients with PDAC.

\section{mRNA expression of $\alpha A$-crystallin in various human pancreatic carcinoma cell lines and nestin-expressing pancreatic cells (HPNE)}

To establish the relative level of mRNA for $\alpha A$ crystallin in various human cancer cell lines, we have performed RT-PCR analysis. As shown in Figure 3A \& 3B, compared with the HPNE cells, various human pancreatic carcinoma cell lines have decreased $\alpha$ A-crystallin mRNA level. Panc-1, Capan-1, FPAC-1, Miapaca-2, and HPAC displayed about $50 \%$ to $60 \%$, Bxpc-3, Hs766-T, and the remaining cell lines less than $40 \%$ of HPNE $\alpha$ A-crystallin mRNA level.

\section{Protein expression of $\alpha A$-crystallin in various human pancreatic carcinoma cell lines and hTERT-pancreas cells}

To investigate the relative level of $\alpha \mathrm{A}$-crystallin protein in various human cancer cell lines, we have conducted Western blot analysis. As shown in Figure $3 \mathrm{C} \& 3 \mathrm{D}$, compared with the $\alpha \mathrm{A}$-crystallin level in HPNE cells, various human pancreatic carcinoma cell lines also showed much decreased $\alpha \mathrm{A}$-crystallin level. The two pancreatic tumor cell lines showing the highest 
$\alpha$ A-crystallin level were Capan-1 and Micpaca-2, which had about $80 \%$ and $65 \%$ of HPNE $\alpha$ A-crystallin. The remaining pancreatic cancer cell lines had less than $40 \%$ of HPNE $\alpha$ A-crystallin.

$\alpha A$-crystallin is localized in the cytoplasm and to a less degree in the nucleus of pancreatic tumor cells

To understand the possible function of the $\alpha \mathrm{A}$ crystallin, we have analyzed its localization in pancreatic cancer cells. As shown in Supplementary Figure S1, immunocytochemical analysis revealed that $\alpha \mathrm{A}$-crystallin was largely localized in the cytoplasm and to a much less degree, in the nucleus of pancreatic cancer cells.

\section{Expression of $\alpha \mathrm{A}$-crystallin in MiaPaCa-1 cells decreases its ability of promoting colony formation}

To analyze the role of $\alpha \mathrm{A}$-crystallin in suppressing pancreatic cancer, we expressed exogenous $\alpha \mathrm{A}$-crystallin in MiaPaCa-1 cells (Figure 4A), which have very little endogenous $\alpha \mathrm{A}$-crystallin and then analyzed the ability of promoting colony formation of these cells. As shown in Figure 4B, 4C \& 4D, MiaPaCa-1 cells expressing $\alpha \mathrm{A}$ crystallin displayed significant decrease in both colony size and colony number (about 3-fold decrease). These results support that $\alpha \mathrm{A}$-crystallin has tumor-suppression functions.
Silence of endogenous $\alpha$ A-crystallin in Capan-1 cells increases its ability of promoting colony formation

To further confirm the role of $\alpha \mathrm{A}$-crystallin in the suppression of pancreatic cancer, we silenced $\alpha \mathrm{A}$ crystallin in Capan-1 cells (Figure 5A), which had relatively moderate endogenous $\alpha \mathrm{A}$-crystallin and then analyzed the ability of promoting colony formation of these cells. As shown in Figure 5B, 5C \& 5D, Capan-1 cells with silenced endogenous $\alpha \mathrm{A}$-crystallin exhibited significant increase in both colony size and colony number (about 5-fold increase). These results further support that $\alpha$ A-crystallin has tumor-suppression function.

\section{Decreased cell migration in $\alpha A$-crystallin- expressing MiaPaCa-1 cells}

To explore how $\alpha$ A-crystallin may regulate carcinogenesis, we conducted wound healing assays using the established stable cell lines: pEGFP-MiaPaCa-1 and pEGFP- $\alpha \mathrm{A}-\mathrm{MiaPaCa}-1$. As shown in Figure $6 \mathrm{~A} \&$ $6 \mathrm{~B}, \mathrm{MiaPaCa}-1$ cells expressing $\alpha \mathrm{A}$-crystallin displayed statistically significant inhibition in cell migration. In contrast, the same cells expressing EGFP-vector did not show such effect. Thus, $\alpha \mathrm{A}$-crystallin also regulates migration of pancreatic cancer cells, which is consistent with its decreased expression in various types of pancreatic carcinoma (Figure 1).

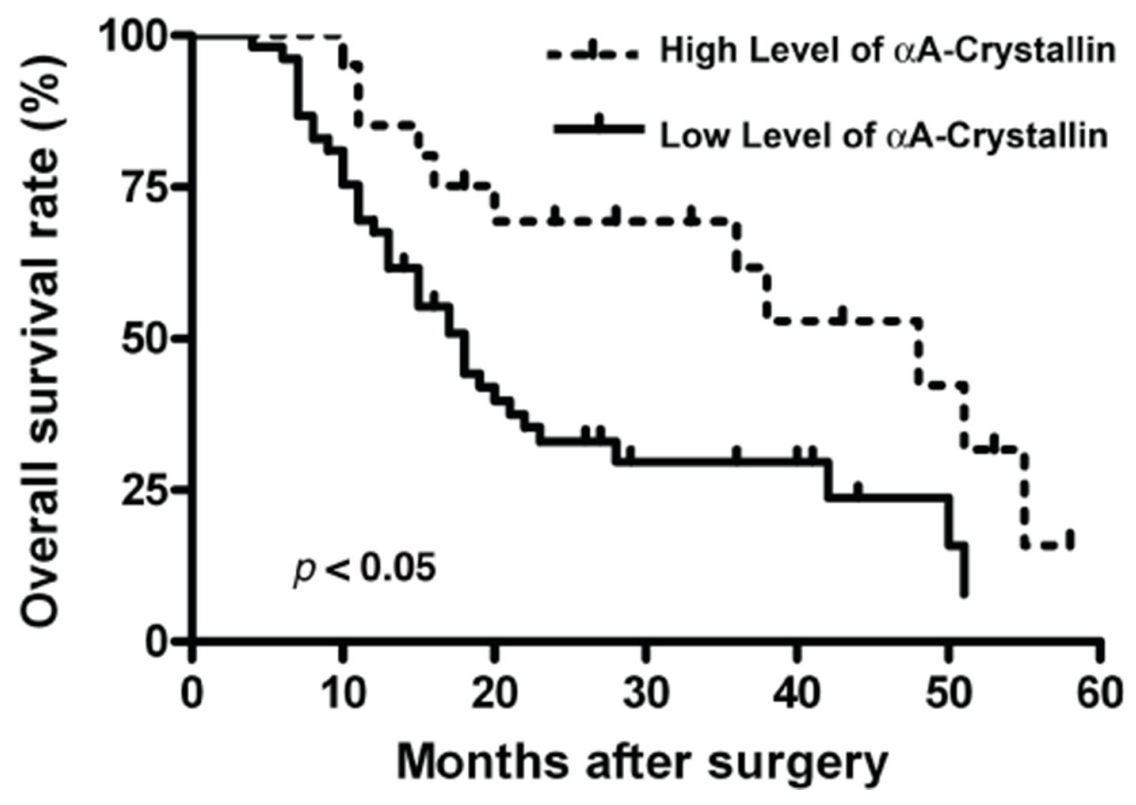

Figure 2: Prognostic significance assessed by Kaplan-Meier survival curves and log-rank tests. Comparison of overall survival (OS) according to $\alpha$ A-crystallin expression. 
Table 2: Multivariate Analyses of Factors Associated with Overall Survival

\begin{tabular}{lcc}
\hline \multirow{2}{*}{ Variable } & OS & \\
\cline { 2 - 3 } & Hazard Ratio & $\boldsymbol{p}$-Value \\
\hline Differentiation (well/ moderate vs poor) & 0.816 & 0.755 \\
PT classification ( pT1/ pT2 vs pT3) & 1.151 & 0.817 \\
Lymph node (pN0 vs pN1) & 0.754 & 0.525 \\
Neural infiltration (yes vs no) & 0.890 & 0.801 \\
$\alpha$ A crystallin (high vs low) & 2.828 & 0.017 \\
\hline
\end{tabular}

\section{Increased cell migration in $\alpha$ A-crystallin- silencing Capan-1 cells}

Since expression of exogenous $\alpha \mathrm{A}$-crystallin in MiaPaCa- 1 cells retards its cell migration in the wound healing assay, we next conducted wound healing assay using the established stable cell lines: vector-Capan-1 and $\alpha$ A-crystallin siRNA plasmid-transfected Capan-1 cells. As shown in Figure 6C \& 6D, Capan-1 cells expressing $\alpha A$-crystallin shRNA displayed statistically significant increase in cell migration. In contrast, the same cells expressing vector did not show such effect. Thus, the tumorigenicity ability of capan-1 cells is also dependent upon the level of the endogenous $\alpha \mathrm{A}$-crystallin.

\section{DISCUSSION}

The $\alpha \mathrm{A}$-crystallin and $\alpha \mathrm{B}$-crystallin are initially known as lens structural proteins with about $60 \%$ identity in amino acid sequence with each another [30-31]. Several lines of evidence have shown that although the two genes encoding $\alpha \mathrm{A}$ - and $\alpha \mathrm{B}$-crystallins seem to arise from gene duplication, they have diverged significantly [32]. First, during mouse development, the two genes are initially turned on at different time. While $\alpha \mathrm{B}$ mRNA is first becoming detectable at E9.5, expression of $\alpha \mathrm{A}$ mRNA appears at E10.5 [32]. Such differential temporal patterns reflect the differential control mechanisms of the two $\alpha$-crystallin gene promoters. Second, the two genes display distinct tissue-specific expression patterns. While $\alpha \mathrm{A}$ is highly restricted to lens during mouse embryonic developmental process, $\alpha \mathrm{B}$-crystallin is expressed in the developing heart, nasal epithelium, and retinal pigment epithelium [33-35]. In the adult vertebrates, although both $\alpha \mathrm{A}$ and $\alpha \mathrm{B}$ are abundantly expressed in the lens, they display significantly difference in non-lenticular tissue expressions. $\alpha \mathrm{B}$ is strongly expressed in heart, skeletal muscle, kidney and brain [34-35]. In contrast, $\alpha \mathrm{A}$ is reported to be expressed at very low level in some nonlenticular tissues including spleen, thymus, heart, brain and liver [35-36]. Our recent studies have shown that $\alpha \mathrm{A}$ is also moderately expressed in normal human and mouse pancreases besides its low level of expression in kidney and liver [28].

Existing evidence suggests both $\alpha \mathrm{A}$ - and $\alpha \mathrm{B}$ crystallins are implicated in carcinogenesis, yet contrast functions have been detected. Iwaki and Tateishi [37] first demonstrated the existence of $\alpha \mathrm{B}$-crystallin in hamartomas of tuberous sclerosis. Then, it was found that concentrations of $\alpha \mathrm{B}$-crystallin in prostatic carcinoma tissues were significantly higher than in benign prostatic hyperplasia [38]. The same group showed that both $\alpha \mathrm{B}-$ crystallin and Hsp27 could be immunohistochemically localized in the normal kidney and renal cell carcinoma tissues. In breast cancer cells, $\alpha \mathrm{B}$-crystallin was found expressing constitutively in certain breast carcinoma cell lines, including those that were capable of metastasizing in immunodeficient mice [39]. Expression of $\alpha B$-crystallin was associated strongly with lymph node involvement, and to a lesser degree, with high nuclear grade [40]. Increased intensity of $\alpha \mathrm{B}$-crystallin expression was correlated with shorter survival [40]. More recently, $\alpha B-$ crystallin was found commonly expressed in basal-like tumors and its expression predicted poor survival in breast cancer patients independent of other prognostic markers [41]. Moreover, expression of $\alpha \mathrm{B}$-crystallin results in transformation of immortalized human mammary epithelial cells, induction of EGF- and anchorageindependent growth, and enhancement of cell migration and invasion [41]. Thus, $\alpha \mathrm{B}$-crystallin seems to be a novel oncoprotein expressed in basal-like breast carcinomas that independently predicts shorter survival [41]. In addition, high level of $\alpha \mathrm{B}$-crystallin was found contributing to the progression of osteosarcoma [42].

Both $\alpha \mathrm{A}-$ and $\alpha \mathrm{B}$-crystallins belong to the heat shock protein (Hsp) family [21]. Compared with $\alpha B-$ crystallin, the limited distribution of $\alpha \mathrm{A}$-crystallin in nonlenticular tissues may restrict its function in carcinogenesis [22-23, 28, 36, 43-44]. Nevertheless, several recent studies suggest that $\alpha \mathrm{A}$-crystallin may be also implicated in tumor development. First, in the noncancerous eyelid, both crystallins were weakly and homogenously 
A

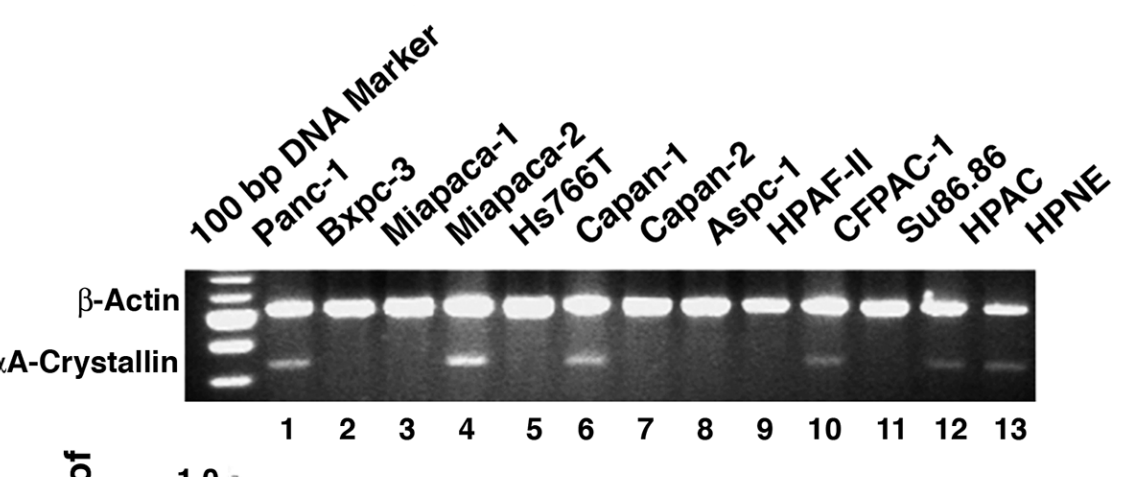

B
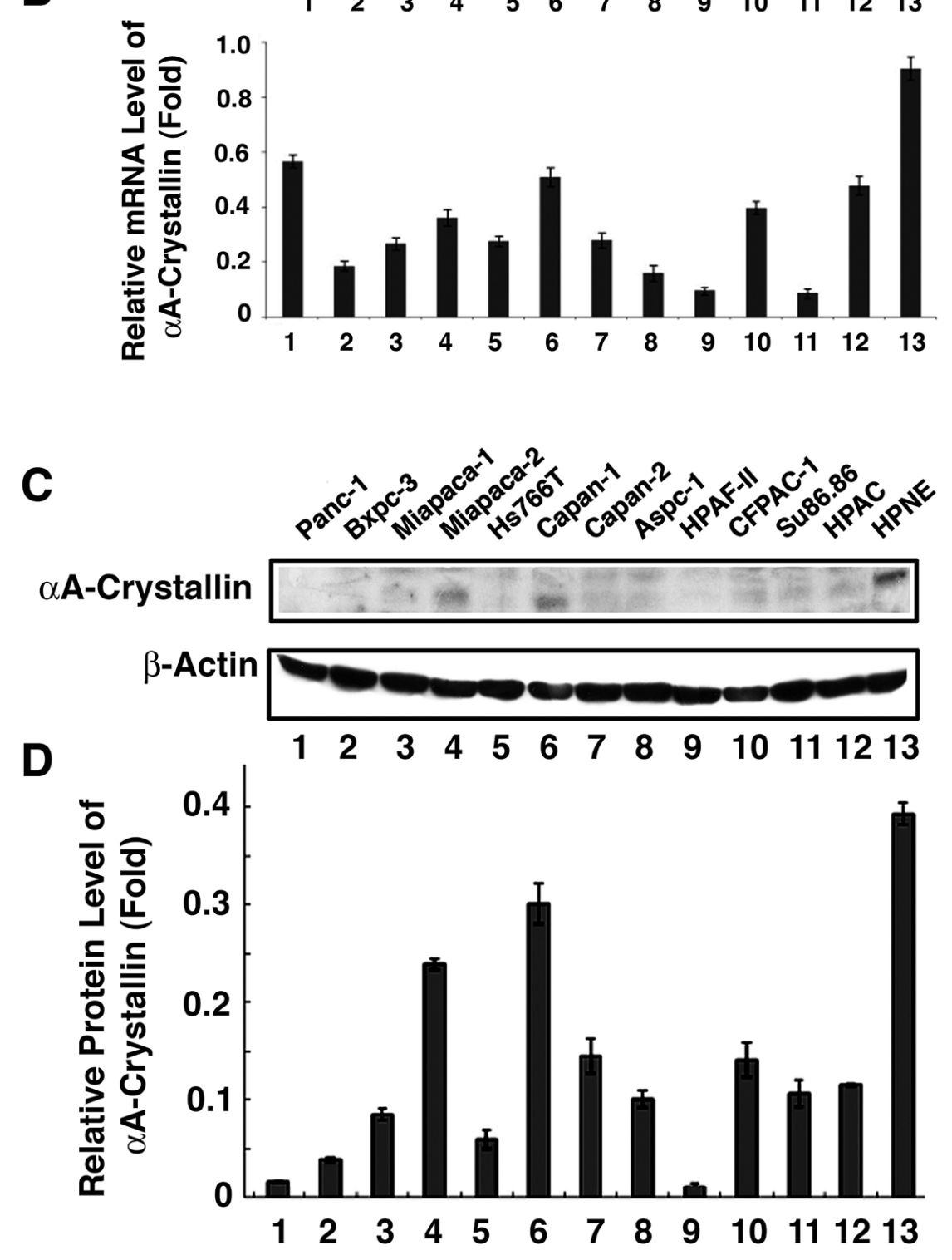

Figure 3: Detection of $\alpha A$-crystallin mRNA and protein expression in pancreatic cancer cell lines. A. mRNA levels of $\alpha$ A-crystallin was determined by semi-quantitative RT-PCR assay. Total RNAs were extracted from 12 pancreatic cell lines (Panc-1, Bxpc3, Miapaca-1, Miapaca-2, Hs766T, Capan-1, Capan-2, Aspc-1, HPAF, CFPAC-1, Su86.86 and HPAC) and HPNE cells (as control), then were used for RT-PCR analyses respectively. B. Western blot assays were performed to detect the expression of $\alpha \mathrm{A}$ crystallin protein in 12 pancreatic cell lines and HPNE cells. Total proteins were prepared and subjected to western blot assay to determine the expression of $\alpha$ Acrystallin protein. $\beta$-actin was used as an internal control. The data shown are representative of three independent experiments. Note that while mRNA was detected in Miapaca-2, Capan-1, Panc-1, CFPAC-1 and HPAC-1, $\alpha$ A-crystallin protein was detected with moderate levels in Miapaca-1 and Capan-1 but much reduced in other pancreatic cancer cell lines in comparison with the control cell, HPNE. 
expressed in the meibomian gland lobules. However, in human sebaceous carcinoma of the eyelid, both $\alpha \mathrm{A}$ crystallin and $\alpha \mathrm{B}$-crystallin were highly expressed in a few cases examined. A statistically significant correlation was observed between expression levels of the two alpha-crystallins in sebaceous carcinomas [43]. Second, in the retinocytoma, $\alpha \mathrm{A}$-crystallin was expressed in the cytoplasm of all tumor cells, whereas $\alpha \mathrm{B}$-crystallin immunoreactivity was only weakly positive [35]. These results suggest that $\alpha \mathrm{A}$-crystallin, acting like $\alpha \mathrm{B}$ - crystallin, seems to promote carcinogenesis. On the other hand, in a recent study where 6 cases of retinoblastoma were subjected to preoperative chemotherapy which induced strong expression of Hsp27 and $\alpha \mathrm{B}$-crystallin but not $\alpha$ A-crystallin [44]. Moreover, the viable tumor cells survived contained high levels of Hsp27 and $\alpha \mathrm{B}-$ crystallin but not $\alpha \mathrm{A}$-crystallin. Therefore, these results indicate that $\alpha \mathrm{A}$-crystallin does not seem to follow the same pattern as Hsp27 and $\alpha B$-crystallin in promoting carcinogenesis. Our recent studies that in 60 different

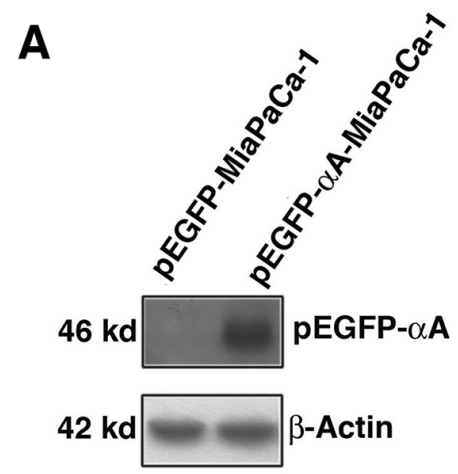

B

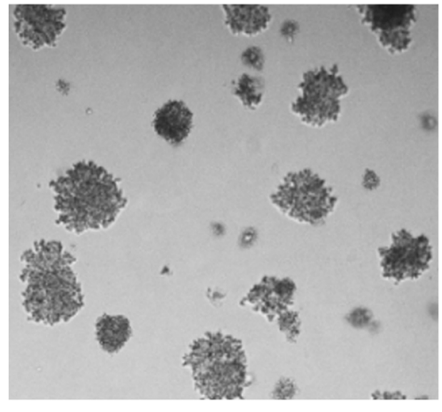

pEGFP-MiaPaCa-1

C

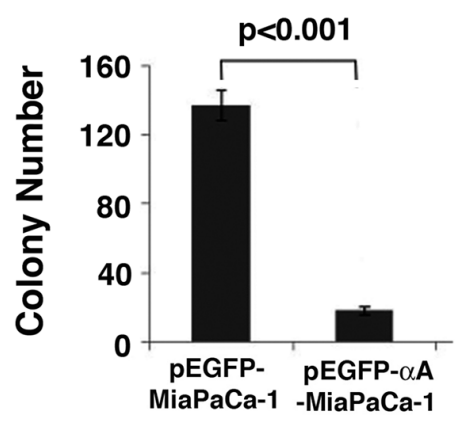

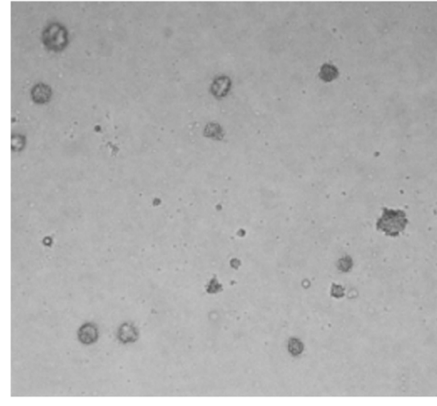

pEGFP- $\alpha$ A-MiaPaCa-1

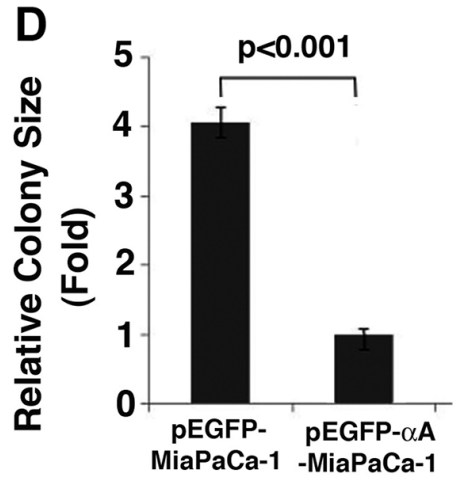

Figure 4: Effects of $\boldsymbol{\alpha A}$-crystallin expression on cell anchorage-independent growth. A. Western blot detection of exogenous $\alpha \mathrm{A}$-crystallin in Miapaca-1 cells stably transfected with vector or $\alpha \mathrm{A}$-crystallin. The stable clones were selected using G418 (400 ng/ $\mathrm{ml}$ ) selection. B. The stable clones, pEGFP-MiaPaCa-1 or pEGFP- $\alpha$ A-Miapaca-1 were used for the soft agar colony formation assays. Representative cell colonies in soft agar are shown here. C. Quantitative analyses of colony numbers and sizes shown in Figure B panels. Values are the means $\pm \mathrm{SD}$ from three independent experiments. 
cases of tissue array samples of pancreatic carcinoma, the expression level of $\alpha \mathrm{A}$-crystallin was consistently decreased than that in 11 normal human pancreas samples also support the inhibition of carcinogenesis by $\alpha \mathrm{A}$ crystallin [28]. In the present study, we demonstrated that expression of $\alpha \mathrm{A}$-crystallin in the para-tumor tissues are significantly stronger than that in pancreatic cancer tissues in 56 out of 74 patients. Thus, while $\alpha \mathrm{B}$-crystallin seems to promote tumorigenesis in prostate and breast cancers, $\alpha \mathrm{A}$-crystallin acts as a tumor suppressor against pancreatic cancer development.

Previous studies have shown that numerous factors may be used as prognosis biomarkers for pancreatic cancer [45-54]. These include receptors, kinases and signaling component [45-48], microRNAs or long non-coding RNAs [49-50], serum factor [51], genome sequence or epigenetic status [52-53]. More recently, it was found that the house keeping gene product,

A

B

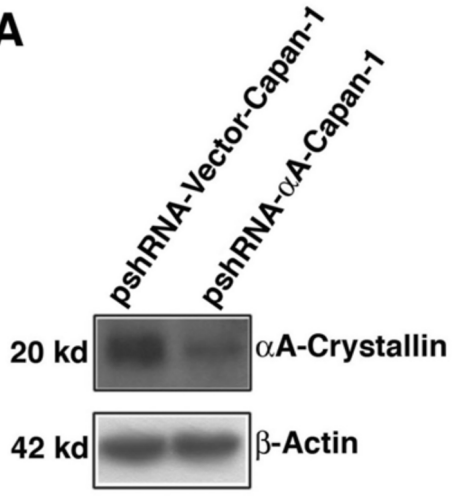

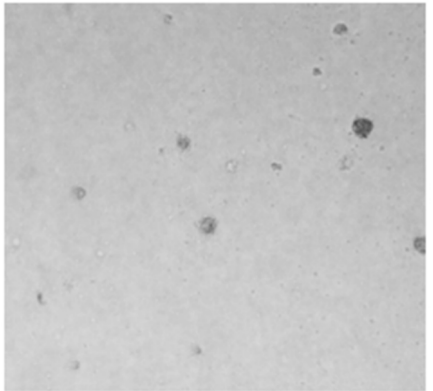

pshRNA-Mock-Capan-1

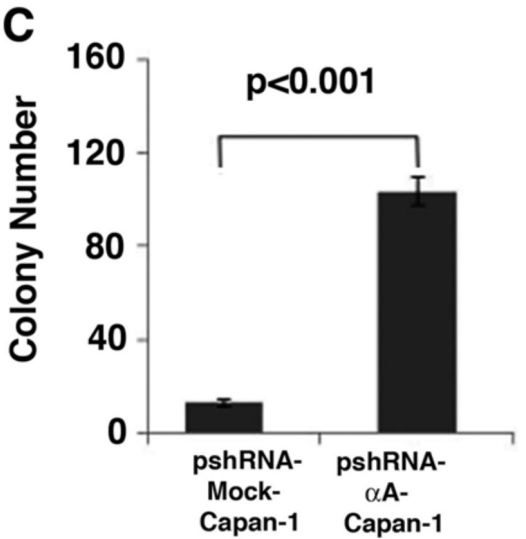

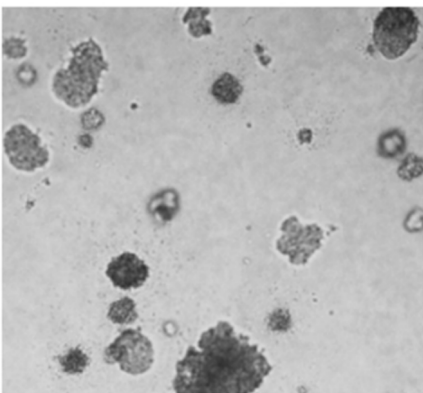

pshRNA- $\alpha$ A-Capan-1

D

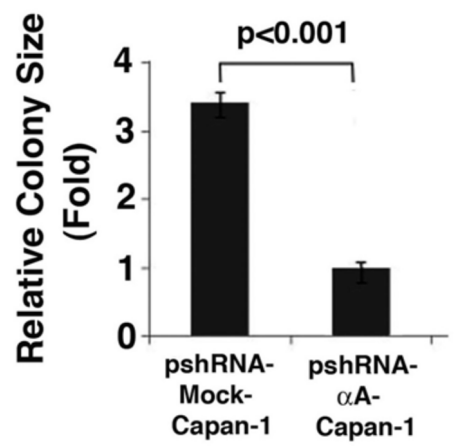

Figure 5: Effects of $\boldsymbol{\alpha A}$-crystallin silence on cell anchorage-independent growth. A. Western blot detection of endogenous $\alpha \mathrm{A}$-crystallin in Capan-1 cells stably transfected with control silence vector, pshRNA-mock; or $\alpha \mathrm{A}$-crystallin silence expression vector, pshRNA- $\alpha$ A and selected with purimycin $(10 \mathrm{ng} / \mathrm{ml})$. B. The stable clones, psh-Mock-Capan-1 or psh- $\alpha \mathrm{A}-\mathrm{Capan}-1$ were used for the soft agar colony formation assays. Representative cell colonies in soft agar are shown here. C. Quantitative analyses of colony numbers and sizes shown in Figure B panels. Values are the means \pm SD from three independent experiments. 
0

A
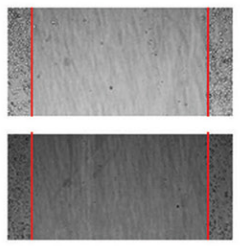

24
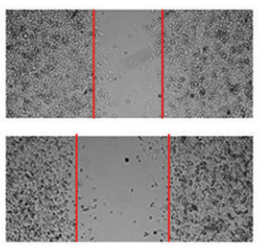

48

(Hrs)

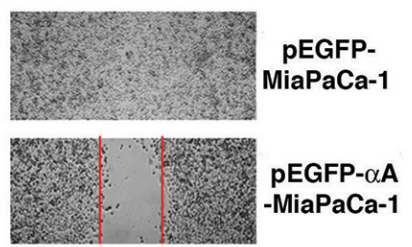

B

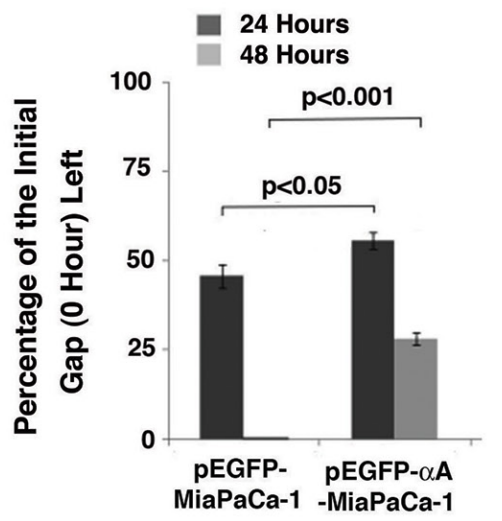

0
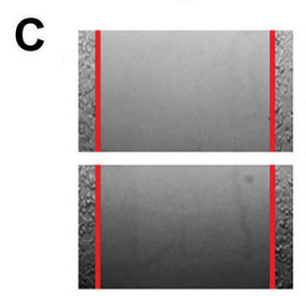

24
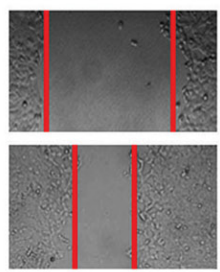

48

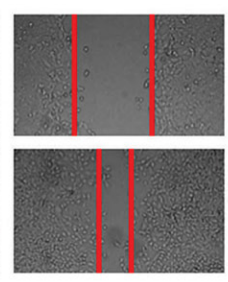

pshRNA-

Mock-

Capan-1

pshRNA-

$\alpha A-$

Capan-1

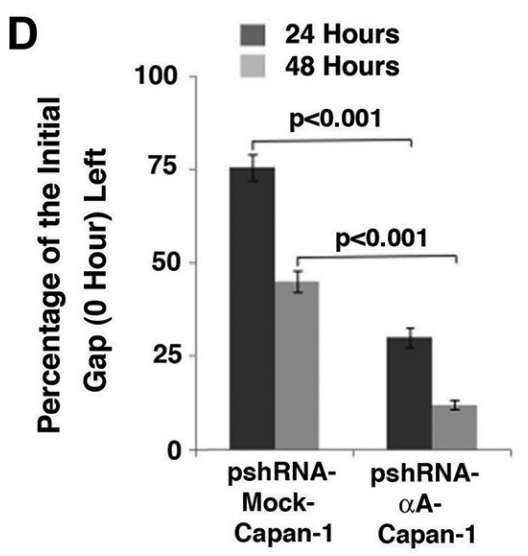

Figure 6: Up-regulation of $\alpha A$-crystallin retards cell migration $A \& B$. and silence of $\alpha A$-crystallin promotes cell migration C \& D. A. Wound healing assay was performed on monolayers of Miapaca-1 cells stably transfected with control vector, or $\alpha \mathrm{A}$-crystallin expression vector. The Representative results were recorded at $0,24 \mathrm{~h}$ and $48 \mathrm{~h}$ after wounds were made. $0 \mathrm{~h}$ was considered as $100 \%$ gap. B. The distance of the wound was measured at 24 and 48 hours along the scratch wound. Values are the means \pm SD from three independent experiments. C. Wound healing assay was performed on monolayers of Capan-1 cells stably transfected with psh-mockvector, or psh- $\alpha \mathrm{A}$-crystallin. The Representative results were recorded at $0,24 \mathrm{~h}$ and $48 \mathrm{~h}$ after wounds were made. $0 \mathrm{~h}$ was considered as $100 \%$ gap. D. The distance of the wound was measured at 24 and 48 hours along the scratch wound. Values are the means \pm SD from three independent experiments. 
$\alpha$-tubulin, could also act as a prognostic biomarker for pancreatic cancer [54]. Our present studies suggest that $\alpha$ A-crystallin, a small heat shock protein, could also act as a prognostic biomarker for pancreatic cancer. First, compared with its physiological level in normal human pancreas, $\alpha \mathrm{A}$-crystallin is significantly decreased in 60 cases of pancreatic carcinomas of various types [28]; Second, our present studies show that the expression level of $\alpha \mathrm{A}$-crystallin in the para-tumor tissues is much stronger than that in the tumor tissues. In contrast, only $21 / 74$ tumor tissue samples displayed some overexpression of $\alpha \mathrm{A}$-crystallin. Finally, when the level of $\alpha \mathrm{A}$-crystallin expression was correlated with the overall survival (OS), it was found that patients with lower level of $\alpha \mathrm{A}$-crystallin expression had less median OS than those with higher level of $\alpha \mathrm{A}$-crystallin expression (18 vs 48 months, Figure 2). Thus, a low level of $\alpha \mathrm{A}$-crystallin expression in pancreatic cancer seems to predict the poor prognosis of patients with PDAC.

Our results also show that in various pancreatic cancer cell lines examined, only two cell lines, Capan-1 and MiaPACA-2, have detectable $\alpha$ A-crystallin in comparison with the normal HPNE cells (Figure 3). Capan-1 was derived from the liver metastasis of a 40-year-old male with PDAC in the head of the pancreas [55]. On the other hand, MiaPaCa-2 was obtained from a 65-year-old male of PDAC with a palpable upper abdominal mass. The tumor involved the body and tail of the pancreas and had infiltrated the periaortic area [56]. Phenotypically, both cell lines can bind to type I collagen [57-60], have similar invasive properties as tested in Matrigel [38, 60-61], but display differential expression level of COX-2 [62-65], and tumorigenicity ability as assayed in xenograted animal [66-68]. Genetically, both cell lines have mutations in Kras [69] and p53 [69-70], homozygous deletions in p16 [70-71]. However, they have contrast genetic background in Smad 4. While Capan-1 has a mutated gene [72-73], MiaPaCa-2 has a wild type Smad4 gene [69-71, 74]. Regardless their similarity and differences in their phenotype and genetic background, our results demonstrated that knockdown of the endogenous $\alpha$ Acrystallin in both cell lines significantly increases their tumorigenicity (Figures $5 \& 6$, and data not shown). On the other hand, expression of $\alpha \mathrm{A}$-crystallin in MiaPaCa-1 and another pancreatic cell line, Capan-2 lacking endogenous $\alpha \mathrm{A}$-crystallin significantly decreased their tumorigenicity as tested in the colony formation and wound healing assays (Figures 4A \& Figure 6, and data not shown). Together, out results demonstrate that $\alpha \mathrm{A}$-crystallin negatively regulates pancreatic tumor development. Lack of $\alpha \mathrm{A}$-crystallin expression in pancreas may be part of the mechanisms initiating development of pancreatic cancer. We are currently characterizing the exact mechanisms by which $\alpha \mathrm{A}$-crystallin suppresses pancreatic tumorigenesis.

\section{MATERIALS AND METHODS}

\section{Reagents and antibodies}

Anti- $\alpha$ A-crystallin antibody was kindly provided by Dr. Joel Horvitz (University of California at Los Angeles). Human normal pancreas cell line, HPNE [29], was provided by Dr. Michel Ouellette (University of Nebraska Medical Center). All pancreatic carcinoma cell lines [7587] were provided by Dr. Min Li (University of Oklahoma Cancer Center).

\section{Patients and tissue samples}

The specimens including tumor and matched adjacent non-tumor tissues that were obtained from 74 patients with PDAC who underwent surgical pancreatic resection without preoperative anticancer treatment at the Cancer Center of Guangzhou Medical University and Southern Medical University between May 2005 and June 2010. Ethical approval for the human subjects was obtained from the Ethics Committees of both universities and informed consent was provided to all patients who were followed for 5 years for complete clinical data. Detailed clinical and pathological parameters are summarized in Table 1. Tumor samples were confirmed by histologists in the hospital and were staged according to the TNM classification system endorsed by the World Health Organization. Overall survival (OS) was computed from the day of surgery to the day of death or to the last follow-up.

\section{Immunohistochemistry}

Formalin-fixed tissues were paraffin-embedded and sectioned for immunostained with anti- $\alpha \mathrm{A}$-crystallin antibody using standard immunohistochemistry procedures as previously described [88-97]. Immunostained slides were evaluated independently by 2 pathologists in double-blind manner. Sections were scored semi-quantitatively for the extent of immunoreaction as follows: $0,0 \%$ immunoreactive cells; $1,<5 \%$ immunoreactive cells; 2, 5-50\% immunoreactive cells; and $3,>50 \%$ immunoreactive cells. Also, the intensity of staining was scored semi-quantitatively as following: 0 , negative; 1 , weak; 2 , intermediate; and 3 , strong. The final immunoreaction score was defined as the sum of both parameters (extension and intensity). The final scores of $<3$ were considered to be low in $\alpha$ A crystallin levels, and scores $\geq 3$ were considered to be high in $\alpha \mathrm{A}$-crystallin expression.

\section{Cell lines, establishment of stable cell lines and cell culture}

Twelve pancreatic cancer cell lines (Panc-1, Bxpc3, Miapaca-1, Miapaca-2, Hs766T, Capan-1, Capan-2, 
Aspc-1, HPAF-II, CFPAC-1, Su86.86 and HPAC) [7587] were analyzed. The immortalized human pancreatic nestin-expressing cells (HPNE) was kindly provided by Dr. Michel Ouellette (University of Nebraska Medical Center) [29]. The $\alpha$ A cDNA was amplified by RT-PCR from human lens mRNA using the following primers: 5'-TACCTCGAGATGGA-CGTGACCATCCAGC-3' ( $\alpha$ A-crystallin, forward), 5'-CAACCCGGGTTAGGACGAGGGAGCCGAG-3' ( $\alpha$ A-crystallin, reverse). The cDNA was further inserted into an enhanced green fluorescence protein expression vector, $\mathrm{pEGFPC} 3$, at the XhoI and SmaI sites that were created by PCR to generate in frame fusion construct. The psiRNA-Vector and psiRNA- $\alpha$ A knockdown constructs were ordered from Santa Cruz Biotechnology (CA). The stable transfected cell clones, pEGFP-Miapaca-1 and pEGFP- $\alpha$ A-Miapaca-1, were selected in the presence of $400 \mu \mathrm{g} / \mathrm{ml}$ neomycin in Dulbecco's Modified Eagle's Minimal Essential Medium (DMEM) containing 10\% fetal bovine serum, 50 units $/ \mathrm{ml}$ penicillin and streptomycin as described before [28]. The stable knockdown clones, psiRNA-Mock-Capan-1 and psiRNA- $\alpha$ A-Capan- 1 were screened through growth with $0.25 \mu \mathrm{g} / \mathrm{ml}$ puromycin in DMEM containing $10 \%$ fetal bovine serum, 50 units $/ \mathrm{ml}$ penicillin and streptomycin for a period of 4 weeks. All cells were kept at $37^{\circ} \mathrm{C}$ and $5 \%$ $\mathrm{CO} 2$ gas phase.

\section{RT-PCR analysis}

The expression level of the mRNA for alphaAcrystallin in human normal and pancreatic carcinoma cell lines were detected using RT-PCR as previously described $(28,88-97)$. RNA extraction was conducted with RNAeasy kit (Invitrogen). Reverse transcription was conducted with $450 \mathrm{ng}$ total RNA and oligo(dT) primers (Promega). The oligonucleotide primers synthesized by Invitrogen, Inc. were as follows: for alpha A, 5'-ATGGACGAGAAGGTGTTC-3' (forward) and 5'-TAACGAACCTTAAG-AGCTAC-3' (reverse) with the amplified fragment of $310 \mathrm{bp}$; and for human $\beta$-actin, 5'-ACATGGCATTGTTACCAAC-3' (forward) and 5'-CGTTGCCAATAGTGA-TGAC-3' (reverse) with the amplified fragment of $541 \mathrm{bp}$. PCR was run 30 cycles with an annealing temperature of $50^{\circ} \mathrm{C}$.

\section{Western blot analysis}

Preparation of total proteins from parent and various transfected cells and Western blot analysis of different protein samples were conducted as previously described [88-97].

\section{Colony formation assay}

$\alpha \mathrm{A}$-crystallin knockdown or over-expression cells or control cells were suspended in a medium containing
$0.33 \%$ agar and overlaid on $0.5 \%$ agar in 6-well plates (500 cells/well) as described before [28, 98]. After 14 days, colonies were counted and photographed. The results were expressed as the means \pm SD of triplicate counts.

\section{Wound healing assay}

Four types of stable clones of pEGFP-Miapaca-1, pEGFP- $\alpha$ A-Miapaca-1, psiRNA-Vector-Capan-1 and psiRNA- $\alpha$ A-Capan cells-1 [28] were seed in 6-well plates and cultured until $100 \%$ confluent. A straight scratch was made by using a $1 \mathrm{ml}$ blue pipette tip to simulate the wound in each well. After PBS washing for 2 times, new DMEM medium was added for a continuous growth of another 48 hours. The wound healing process was recorded daily using the Leica Fluorescence Microscopy with a 10x objective as described before [28, 98].

\section{Statistical analysis}

The student $t$-test was used to compare the mean of two unpaired groups. $P<0.05$ was considered significant $[28,98]$. The Chi-square test was used to study the association between two categorical variables. A Kaplan-Meier plot and log rank test were used to study the association between the overall survival of patients and the expression of $\alpha \mathrm{A}$-crystallin. The Cox proportional hazards regression model was used to study the association between the overall survival of patients and the expression of $\alpha \mathrm{A}$-crystallin by adjusting for other potential confounders.

\section{ACKNOWLEDGMENTS}

We thank Dr. J. Horvitz for the aA-crystallin antibody, Dr. Min Li for pancreatic cancer cell lines and Dr. Michel Ouellette for the HPNE cell line. This work is supported in part by the National Natural Science Foundation of China grants 81272228 and 81570824 , the NIH Grant 1R01EY018380, Research Prevent Blindness, the fundamental research funds from the State Key Laboratory of Ophthalmology in Zhongshan Ophthalmic Center of Sun Yat-sen University, and the Lotus Scholar Program Funds from Hunan Province Government and Hunan Normal University, the Cooperative Innovation Center of Engineering and New Products for Developmental Biology of Hunan Province (20134486), and the Chinese Scholarship Council [WKJ, WFH, XHH, LW, ZXH, ZFW].

\section{CONFLICTS OF INTEREST}

The authors declare no conflicts of interest. 


\section{REFERENCES}

1. Siegel RL, Miller KD, Jemal A. Cancer statistics, 2015. CA Cancer J Clin. 2015; 65:5-29.

2. Rahib L, Smith BD, Aizenberg R, Rosenzweig AB, Fleshman JM, Matrisian LM. Projecting cancer incidence and deaths to 2030: the unexpected burden of thyroid, liver, and pancreas cancers in the United States. Cancer Res. 2014; 74:2913-21.

3. Pezzilli R. Pancreatic ductal carcinoma: from the bench to the bedside. JOP. 2006; 7:508-10.

4. Hruban RH, Adsay NV, Albores-Saavedra J, Compton C, Garrett ES, Goodman SN, Kern SE, Klimstra DS, Klöppel G, Longnecker DS, Lüttges J, Offerhaus GJ. Pancreatic intraepithelial neoplasia: a new nomenclature and classification system for pancreatic duct lesions. Am J Surg Pathol. 2001; 25:579-86.

5. Hezel AF, Kimmelman AC, Stanger BZ, Bardeesy N, Depinho RA. Genetics and biology of pancreatic ductal adenocarcinoma. Genes Dev. 2006; 20:1218-49.

6. Bardeesy N, DePinho RA. Pancreatic cancer biology and genetics. Nat Rev Cancer. 2002; 2:897-909.

7. Rustgi AK. The molecular pathogenesis of pancreatic cancer: clarifying a complex circuitry. Genes Dev. 2006; 20:3049-53.

8. Aguirre AJ, Bardeesy N, Sinha M, Lopez L, Tuveson DA, Horner J, Redston MS, DePinho RA. Activated Kras and Ink4a/Arf deficiency cooperate to produce metastatic pancreatic ductal adenocarcinoma. Genes Dev. 2003; 17:3112-26.

9. Abraham SC, Wu TT, Klimstra DS, Finn LS, Lee JH, Yeo CJ, Cameron JL, Hruban RH. Distinctive molecular genetic alterations in sporadic and familial adenomatous polyposisassociated pancreatoblastomas : frequent alterations in the APC/beta-catenin pathway and chromosome 11p. Am J Pathol. 2001; 159:1619-27.

10. Bardeesy N, Cheng KH, Berger JH, Chu GC, Pahler J, Olson P, Hezel AF, Horner J, Lauwers GY, Hanahan D, DePinho RA. Smad4 is dispensable for normal pancreas development yet critical in progression and tumor biology of pancreas cancer. Genes Dev. 2006; 20:3130-46.

11. Ijichi H, Chytil A, Gorska AE, Aakre ME, Fujitani Y, Fujitani S, Wright CV, Moses HL. Aggressive pancreatic ductal adenocarcinoma in mice caused by pancreas-specific blockade of transforming growth factor-beta signaling in cooperation with active Kras expression. Genes Dev. 2006; 20:3147-60.

12. Pasca di Magliano M, Sekine S, Ermilov A, Ferris J, Dlugosz AA, Hebrok M. Hedgehog/Ras interactions regulate early stages of pancreatic cancer. Genes Dev. 2006; 20:3161-73.

13. Morris JP 4th, Wang SC, Hebrok M. KRAS, Hedgehog, Wnt and the twisted developmental biology of pancreatic ductal adenocarcinoma. Nat Rev Cancer. 2010; 10:683-95.
14. Izeradjene $\mathrm{K}$, Combs $\mathrm{C}$, Best $\mathrm{M}$, Gopinathan $\mathrm{A}$, Wagner $\mathrm{A}$, Grady WM, Deng CX, Hruban RH, Adsay NV, Tuveson DA, Hingorani SR. Kras(G12D) and Smad4/Dpc4 haploinsufficiency cooperate to induce mucinous cystic neoplasms and invasive adenocarcinoma of the pancreas. Cancer Cell. 2007; 11:229-43.

15. Bardeesy N, Aguirre AJ, Chu GC, Cheng KH, Lopez LV, Hezel AF, Feng B, Brennan C, Weissleder R, Mahmood U, Hanahan D, Redston MS, Chin L, Depinho RA. Both p16(Ink4a) and the p19(Arf)-p53 pathway constrain progression of pancreatic adenocarcinoma in the mouse. Proc Natl Acad Sci USA. 2006; 103:5947-52.

16. Waddell N, Pajic M, Patch AM, Chang DK, Kassahn KS, Bailey P, Johns AL, Miller D, Nones K, Quek K, Quinn MC, Robertson AJ, Fadlullah MZ, et al, and Australian Pancreatic Cancer Genome Initiative. Whole genomes redefine the mutational landscape of pancreatic cancer. Nature. 2015; 518:495-501.

17. Biankin AV, Waddell N, Kassahn KS, Gingras MC, Muthuswamy LB, Johns AL, Miller DK, Wilson PJ, Patch AM, Wu J, Chang DK, Cowley MJ, Gardiner BB, et al. Pancreatic cancer genomes reveal aberrations in axon guidance pathway genes. Nature. 2012; 491:399-405.

18. Benndorf R, Welsh MJ. Shocking degeneration. Nat Genet. 2004; 36:547-48.

19. Sun Y, MacRae TH. The small heat shock proteins and their role in human disease. FEBS J. 2005; 272:2613-27

20. Bennardini F, Wrzosek A, Chiesi M. Alpha B-crystallin in cardiac tissue. Association with actin and desmin filaments. Circ Res. 1992; 71:288-94.

21. Li DW, Gong LL, Deng M, Liu JP, Liu M, Mao YW. (2009). The two lens structural proteins, $\alpha \mathrm{A}$ - and $\alpha \mathrm{B}$-crystallins, prevent stress-induced apoptosis through regulation of multiple signaling transduction pathways. In: Arrigo, Simon, eds. Small Stress Proteins and Human Diseases, Nova Science Publisher, Inc NY, USA, Chapter 1.1, pp. 89-116.

22. Benjamin IJ, Guo Y, Srinivasan S, Boudina S, Taylor RP, Rajasekaran NS, Gottlieb R, Wawrousek EF, Abel ED, Bolli R. CRYAB and HSPB2 deficiency alters cardiac metabolism and paradoxically confers protection against myocardial ischemia in aging mice. Am J Physiol Heart Circ Physiol. 2007; 293:H3201-09.

23. Sherman M, Multhoff G. Heat shock proteins in cancer. Ann N Y Acad Sci. 2007; 1113:192-201.

24. Didelot C, Lanneau D, Brunet M, Joly AL, De Thonel A, Chiosis G, Garrido C. Anti-cancer therapeutic approaches based on intracellular and extracellular heat shock proteins. Curr Med Chem. 2007; 14:2839-47.

25. Ciocca DR, Calderwood SK. Heat shock proteins in cancer: diagnostic, prognostic, predictive, and treatment implications. Cell Stress Chaperones. 2005; 10:86-103.

26. Chen P, Ji W, Liu FY, Tang HZ, Fu S, Zhang X, Liu M, Gong L, Deng M, Hu WF, Hu XH, Chen XW, Li ZL, et al. 
Alpha-crystallins and tumorigenesis. Curr Mol Med. 2012; 12:1164-73.

27. Kato K, Shinohara H, Kurobe N, Goto S, Inaguma Y, Ohshima K. Immunoreactive alpha A crystallin in rat nonlenticular tissues detected with a sensitive immunoassay method. Biochim Biophys Acta. 1991; 1080:173-80.

28. Deng M, Chen PC, Xie S, Zhao J, Gong L, Liu J, Zhang L, Sun S, Liu J, Ma H, Batra SK, Li DW. The small heat shock protein alphaA-crystallin is expressed in pancreas and acts as a negative regulator of carcinogenesis. Biochim Biophys Acta. 2010; 1802:621-31.

29. Lee KM, Yasuda H, Hollingsworth MA, Ouellette MM. Notch 2-positive progenitors with the intrinsic ability to give rise to pancreatic ductal cells. Lab Invest. 2005; 85:1003-12.

30. Reddy GB, Kumar PA, Kumar MS. Chaperone-like activity and hydrophobicity of alpha-crystallin. IUBMB Life. 2006; 58:632-41.

31. Piatigorsky J. Lens crystallins and their genes: diversity and tissue-specific expression. FASEB J. 1989; 3:1933-40.

32. Robinson ML, Overbeek PA. Differential expression of alpha A- and alpha B-crystallin during murine ocular development. Invest Ophthalmol Vis Sci. 1996; 37:2276-84.

33. Bhat SP, Nagineni CN. alpha B subunit of lens-specific protein alpha-crystallin is present in other ocular and nonocular tissues. Biochem Biophys Res Commun. 1989; 158:319-25.

34. Dubin RA, Wawrousek EF, Piatigorsky J. Expression of the murine alpha B-crystallin gene is not restricted to the lens. Mol Cell Biol. 1989; 9:1083-91.

35. Kase S, Parikh JG, Rao NA. Expression of alpha-crystallin in retinoblastoma. Arch Ophthalmol. 2009; 127:187-92.

36. Srinivasan AN, Nagineni CN, Bhat SP. alpha A-crystallin is expressed in non-ocular tissues. J Biol Chem. 1992; 267:23337-41.

37. Iwaki T, Tateishi J. Immunohistochemical demonstration of alphaB-crystallin in hamartomas of tuberous sclerosis. Am J Pathol. 1991; 139:1303-08.

38. Takashi M, Katsuno S, Sakata T, Ohshima S, Kato K. Different concentrations of two small stress proteins, alphaB crystallin and HSP27 in human urological tumor tissues. Urol Res. 1998; 26:395-99.

39. Ou K, Yu K, Kesuma D, Hooi M, Huang N, Chen W, Lee SY, Goh XP, Tan LK, Liu J, Soon SY, Bin Abdul Rashid S, Putti TC, et al. Novel breast cancer biomarkers identified by integrative proteomic and gene expression mapping. J Proteome Res. 2008; 7:1518-28.

40. Chelouche-Lev D, Kluger HM, Berger AJ, Rimm DL, Price JE. alphaB-crystallin as a marker of lymph node involvement in breast carcinoma. Cancer. 2004; 100:2543-48.

41. Moyano JV, Evans JR, Chen F, Lu M, Werner ME, Yehiely F, Diaz LK, Turbin D, Karaca G, Wiley E, Nielsen
TO, Perou CM, Cryns VL. AlphaB-crystallin is a novel oncoprotein that predicts poor clinical outcome in breast cancer. J Clin Invest. 2006; 116:261-70.

42. Shi QM, Luo J, Wu K, Yin M, Gu YR, Cheng XG. High level of $\alpha \mathrm{B}$-crystallin contributes to the progression of osteosarcoma. Oncotarget. 2016; 7:9007-16. doi: 10.18632/ oncotarget.6928.

43. Rigas PK, Kase S, Rao NA. Expression of alpha-crystallins in human sebaceous carcinoma of the eyelid. Eur J Ophthalmol. 2009; 19:702-07.

44. Kase S, Parikh JG, Rao NA. Expression of heat shock protein 27 and alpha-crystallins in human retinoblastoma after chemoreduction. Br J Ophthalmol. 2009; 93:541-44.

45. Huang J, Fan X, Wang X, Lu Y, Zhu H, Wang W, Zhang S, Wang Z. High ROR2 expression in tumor cells and stroma is correlated with poor prognosis in pancreatic ductal adenocarcinoma. Sci Rep. 2015; 5:12991.

46. Huo Y, Yang M, Liu W, Yang J, Fu X, Liu D, Li J, Zhang J, Hua R, Sun Y. High expression of DDR1 is associated with the poor prognosis in Chinese patients with pancreatic ductal adenocarcinoma. J Exp Clin Cancer Res. 2015; 34:88.

47. Zhang Y, Jiang H, Qin M, Su X, Cao Z, Wang J. TNIK serves as a novel biomarker associated with poor prognosis in patients with pancreatic cancer. Tumour Biol. 2016; 37:1035-40.

48. Yang JY, Yang MW, Huo YM, Liu W, Liu DJ, Li J, Zhang JF, Hua R, Sun YW. High expression of WISP-1 correlates with poor prognosis in pancreatic ductal adenocarcinoma. Am J Transl Res. 2015; 7:1621-28.

49. Miyamae M, Komatsu S, Ichikawa D, Kawaguchi T, Hirajima S, Okajima W, Ohashi T, Imamura T, Konishi H, Shiozaki A, Morimura R, Ikoma H, Ochiai T, et al. Plasma microRNA profiles: identification of miR-744 as a novel diagnostic and prognostic biomarker in pancreatic cancer. Br J Cancer. 2015; 113:1467-76.

50. Sun XL, Cao GH, Cao Y, Jiang X, Li XK, Ye XH, Wang DH, Yan SX. Association of LncRNA HMlincRNA717 with prognosis in pancreatic cancer. Eur Rev Med Pharmacol Sci. 2016; 20:2230-34.

51. Liu L, Xu HX, Wang WQ, Wu CT, Xiang JF, Liu C, Long J, Xu J, Fu L, Ni QX, Houchen CW, Postier RG, Li M, Yu XJ. Serum CA125 is a novel predictive marker for pancreatic cancer metastasis and correlates with the metastasisassociated burden. Oncotarget. 2016; 7:5943-56. doi: 10.18632/oncotarget.6819.

52. Stracquadanio G, Vrugt B, Flury R, Schraml P, Würl P, Müller TH, Knippschild U, Henne-Bruns D, Breitenstein S, Clavien PA, Graf R, Bond GL, Grochola LF. CD44 SNP rs187115: A novel biomarker signature that predicts survival in resectable pancreatic ductal adenocarcinoma. Clin Cancer Res. 2016; 22:6069-77.

53. Yokoyama S, Higashi M, Kitamoto S, Oeldorf M, Knippschild U, Kornmann M, Maemura K, Kurahara H, Wiest E, Hamada T, Kitazono I, Goto Y, Tasaki T, et al. 
Aberrant methylation of MUC1 and MUC4 promoters are potential prognostic biomarkers for pancreatic ductal adenocarcinomas. Oncotarget. 2016; 7:42553-65. doi: 10.18632/oncotarget.9924.

54. Lin C, Zhao GC, Xu YD, Wang DS, Jin DY, Ji Y, Lou WH, $\mathrm{Wu}$ WC. Increased expression of $\alpha$ Tubulin is associated with poor prognosis in patients with pancreatic cancer after surgical resection. Oncotarget. 2016; 7:60657-64. doi: 10.18632/oncotarget.10630.

55. Kyriazis AP, Kyriazis AA, Scarpelli DG, Fogh J, Rao MS, Lepera R. Human pancreatic adenocarcinoma line Capan-1 in tissue culture and the nude mouse: morphologic, biologic, and biochemical characteristics. Am J Pathol. 1982; 106:250-60.

56. Yunis AA, Arimura GK, Russin DJ. Human pancreatic carcinoma (MIA PaCa-2) in continuous culture: sensitivity to asparaginase. Int J Cancer. 1977; 19:128-35.

57. McIntyre LJ, Kim YS. Effects of sodium butyrate and dimethylsulfoxide on human pancreatic tumor cell lines. Eur J Cancer Clin Oncol. 1984; 20:265-71.

58. Greco E, Basso D, Fogar P, Mazza S, Navaglia F, Zambon CF, Falda A, Pedrazzoli S, Ancona E, Plebani M. Pancreatic cancer cells invasiveness is mainly affected by interleukin1beta not by transforming growth factor-beta1. Int J Biol Markers. 2005; 20:235-41.

59. Navaglia F, Fogar P, Greco E, Basso D, Stefani AL, Mazza S, Zambon CF, Habeler W, Altavilla G, Amadori A, Cecchetto A, Plebani M. CD44v10: an antimetastatic membrane glycoprotein for pancreatic cancer. Int J Biol Markers. 2003; 18:130-38.

60. Shirk AJ, Kuver R. Epidermal growth factor mediates detachment from and invasion through collagen I and Matrigel in Capan-1 pancreatic cancer cells. BMC Gastroenterol. 2005; 5:12.

61. Stefani AL, Basso D, Panozzo MP, Greco E, Mazza S, Zancanaro F, De Franchis G, Plebani M. Cytokines modulate MIA PaCa 2 and CAPAN-1 adhesion to extracellular matrix proteins. Pancreas. 1999; 19:362-69.

62. Ellenrieder V, Hendler SF, Ruhland C, Boeck W, Adler G, Gress TM. TGF-beta-induced invasiveness of pancreatic cancer cells is mediated by matrix metalloproteinase- 2 and the urokinase plasminogen activator system. Int J Cancer. 2001; 93:204-11.

63. Eibl G, Bruemmer D, Okada Y, Duffy JP, Law RE, Reber HA, Hines OJ. PGE(2) is generated by specific COX-2 activity and increases VEGF production in COX2-expressing human pancreatic cancer cells. Biochem Biophys Res Commun. 2003; 306:887-97.

64. Eibl G, Reber HA, Wente MN, Hines OJ. The selective cyclooxygenase-2 inhibitor nimesulide induces apoptosis in pancreatic cancer cells independent of COX-2. Pancreas. 2003; 26:33-41.

65. Molina MA, Sitja-Arnau M, Lemoine MG, Frazier ML, Sinicrope FA. Increased cyclooxygenase-2 expression in human pancreatic carcinomas and cell lines: growth inhibition by nonsteroidal anti-inflammatory drugs. Cancer Res. 1999; 59:4356-62.

66. Yip-Schneider MT, Sweeney CJ, Jung SH, Crowell PL, Marshall MS. Cell cycle effects of nonsteroidal antiinflammatory drugs and enhanced growth inhibition in combination with gemcitabine in pancreatic carcinoma cells. J Pharmacol Exp Ther. 2001; 298:976-85.

67. Fogar P, Greco E, Basso D, Habeler W, Navaglia F, Zambon CF, Tormen D, Gallo N, Cecchetto A, Plebani M, Pedrazzoli S. Suicide gene therapy with HSV-TK in pancreatic cancer has no effect in vivo in a mouse model. Eur J Surg Oncol. 2003; 29:721-30.

68. Hotz HG, Reber HA, Hotz B, Yu T, Foitzik T, Buhr HJ, Cortina G, Hines OJ. An orthotopic nude mouse model for evaluating pathophysiology and therapy of pancreatic cancer. Pancreas. 2003; 26:e89-98.

69. Fukushima N, Sato N, Ueki T, Rosty C, Walter KM, Wilentz RE, Yeo CJ, Hruban RH, Goggins M. Aberrant methylation of preproenkephalin and p16 genes in pancreatic intraepithelial neoplasia and pancreatic ductal adenocarcinoma. Am J Pathol. 2002; 160:1573-81.

70. Caldas C, Hahn SA, da Costa LT, Redston MS, Schutte M, Seymour AB, Weinstein CL, Hruban RH, Yeo CJ, Kern SE. Frequent somatic mutations and homozygous deletions of the p16 (MTS1) gene in pancreatic adenocarcinoma. Nat Genet. 1994; 8:27-32.

71. Huang L, Goodrow TL, Zhang SY, Klein-Szanto AJ, Chang H, Ruggeri BA. Deletion and mutation analyses of the P16/ MTS-1 tumor suppressor gene in human ductal pancreatic cancer reveals a higher frequency of abnormalities in tumorderived cell lines than in primary ductal adenocarcinomas. Cancer Res. 1996; 56:1137-41.

72. Loukopoulos P, Kanetaka K, Takamura M, Shibata T, Sakamoto M, Hirohashi S. Orthotopic transplantation models of pancreatic adenocarcinoma derived from cell lines and primary tumors and displaying varying metastatic activity. Pancreas. 2004; 29:193-203.

73. Schutte M, Hruban RH, Hedrick L, Cho KR, Nadasdy GM, Weinstein CL, Bova GS, Isaacs WB, Cairns P, Nawroz H, Sidransky D, Casero RA Jr, Meltzer PS, et al. DPC4 gene in various tumor types. Cancer Res. 1996; 56:2527-30.

74. Sun C, Yamato T, Furukawa T, Ohnishi Y, Kijima H, Horii A. Characterization of the mutations of the K-ras, p53, p16, and SMAD4 genes in 15 human pancreatic cancer cell lines. Oncol Rep. 2001; 8:89-92.

75. Deer EL, González-Hernández J, Coursen JD, Shea JE, Ngatia J, Scaife CL, Firpo MA, Mulvihill SJ. Phenotype and genotype of pancreatic cancer cell lines. Pancreas. 2010; 39:425-35.

76. Hwang CI, Boj SF, Clevers H, Tuveson DA. Preclinical models of pancreatic ductal adenocarcinoma. J Pathol. 2016; 238:197-204. 
77. Chen WH, Horoszewicz JS, Leong SS, Shimano T, Penetrante R, Sanders WH, Berjian R, Douglass HO, Martin EW, Chu TM. Human pancreatic adenocarcinoma: in vitro and in vivo morphology of a new tumor line established from ascites. In Vitro. 1982; 18:24-34.

78. Tan MH, Nowak NJ, Loor R, Ochi H, Sandberg AA, Lopez C, Pickren JW, Berjian R, Douglass HO Jr, Chu TM. Characterization of a new primary human pancreatic tumor line. Cancer Invest. 1986; 4:15-23.

79. Kyriazis AP, Kyriazis AA, Scarpelli DG, Fogh J, Rao MS, Lepera R. Human pancreatic adenocarcinoma line Capan-1 in tissue culture and the nude mouse: morphologic, biologic, and biochemical characteristics. Am J Pathol. 1982; 106:250-60.

80. Kyriazis AA, Kyriazis AP, Sternberg CN, Sloane NH, Loveless JD. Morphological, biological, biochemical, and karyotypic characteristics of human pancreatic ductal adenocarcinoma Capan-2 in tissue culture and the nude mouse. Cancer Res. 1986; 46:5810-15.

81. Schoumacher RA, Ram J, Iannuzzi MC, Bradbury NA, Wallace RW, Hon CT, Kelly DR, Schmid SM, Gelder FB, Rado TA, Frizzell RA. A cystic fibrosis pancreatic adenocarcinoma cell line. Proc Natl Acad Sci USA. 1990; 87:4012-16.

82. Gower WR Jr, Risch RM, Godellas CV, Fabri PJ. HPAC, a new human glucocorticoid-sensitive pancreatic ductal adenocarcinoma cell line. In Vitro Cell Dev Biol Anim. 1994; 30A:151-61.

83. Metzgar RS, Gaillard MT, Levine SJ, Tuck FL, Bossen EH, Borowitz MJ. Antigens of human pancreatic adenocarcinoma cells defined by murine monoclonal antibodies. Cancer Res. 1982; 42:601-08.

84. Owens RB, Smith HS, Nelson-Rees WA, Springer EL. Epithelial cell cultures from normal and cancerous human tissues. J Natl Cancer Inst. 1976; 56:843-49.

85. Smith HS. In vitro properties of epithelial cell lines established from human carcinomas and nonmalignant tissue. J Natl Cancer Inst. 1979; 62:225-30.

86. Yunis AA, Arimura GK, Russin DJ. Human pancreatic carcinoma (MIA PaCa-2) in continuous culture: sensitivity to asparaginase. Int J Cancer. 1977; 19:128-35.

87. Lieber M, Mazzetta J, Nelson-Rees W, Kaplan M, Todaro G. Establishment of a continuous tumor-cell line (panc-1) from a human carcinoma of the exocrine pancreas. Int $\mathrm{J}$ Cancer. 1975; 15:741-47.

88. Qin J, Chen HG, Yan Q, Deng M, Liu J, Doerge S, Ma W, Dong Z, Li DW. Protein phosphatase-2A is a target of epigallocatechin-3-gallate and modulates p53-Bak apoptotic pathway. Cancer Res. 2008; 68:4150-62.
89. Mao YW, Liu JP, Xiang H, Li DW. Human alphaA- and alphaB-crystallins bind to $\mathrm{Bax}$ and $\mathrm{Bcl}-\mathrm{X}(\mathrm{S})$ to sequester their translocation during staurosporine-induced apoptosis. Cell Death Differ. 2004; 11:512-26.

90. Chen PC, Li C, Wang D, Luo ZW, Fu SJ, Li X, Li ZL, Chen XW, Li L, Huang ZX, Ji WK, Hu WF, Hu XH, et al. PP- $1 \alpha$ and PP-1 $\gamma$ display antagonism and differential roles in tumorigenicity of lung cancer cells. Curr Mol Med. 2013; 13:220-27.

91. Deng M, Chen P, Liu F, Fu S, Tang H, Fu Y, Xiong Z, Hui S, Ji W, Zhang X, Zhang L, Gong L, Hu X, et al. The p53-Bak apoptotic signaling axis plays an essential role in regulating differentiation of the ocular lens. Curr Mol Med. 2012; 12:901-16.

92. Huang XQ, Huang ZX, Li ZL, Chen XW, Li X, Tang XC, Liu FY, Liu Y, Chen L, Han WJ, Liu L, Li L, Wu KL, et al. C-Jun terminal kinases play an important role in regulating embryonic survival and eye development in vertebrates. Curr Mol Med. 2013; 13:228-37.

93. Li L, Wang L, Li TT, Li X, Huang XQ, Chen XW, Li ZL, Lv XM, Liu FY, Luo ZW, Liu M, Hu XH, Hu WF, et al. ERK signaling pathway regulates embryonic survival and eye development in goldfish, Carassius auratus. Curr Mol Med. 2013; 13:959-67.

94. Feng H, Xiang H, Mao YW, Wang J, Liu JP, Huang XQ, Liu Y, Liu SJ, Luo C, Zhang XJ, Liu Y, Li DW. Human Bcl-2 activates ERK signaling pathway to regulate activating protein-1, lens epithelium-derived growth factor and downstream genes. Oncogene. 2004; 23:7310-21.

95. Xiao L, Gong LL, Yuan D, Deng M, Zeng XM, Chen LL, Zhang L, Yan Q, Liu JP, Hu XH, Sun SM, Liu J, Ma HL, et al. Protein phosphatase-1 regulates Akt1 signal transduction pathway to control gene expression, cell survival and differentiation. Cell Death Differ. 2010; 17:1448-62.

96. Gong L, Ji WK, Hu XH, Hu WF, Tang XC, Huang ZX, Li L, Liu M, Xiang SH, Wu E, Woodward Z, Liu YZ, Nguyen QD, Li DW. Sumoylation differentially regulates $\mathrm{Sp} 1$ to control cell differentiation. Proc Natl Acad Sci USA. 2014; 111:5574-79.

97. Hu WF, Gong L, Cao Z, Ma H, Ji W, Deng M, Liu M, Hu $\mathrm{XH}$, Chen P, Yan Q, Chen HG, Liu J, Sun S, et al. $\alpha \mathrm{A}$ - and $\alpha \mathrm{B}$-crystallins interact with caspase- 3 and Bax to guard mouse lens development. Curr Mol Med. 2012; 12:177-87.

98. Liu Z, Deng M, Xiang J, Ma H, Hu W, Zhao Y, Li DW, Liang S. A novel spider peptide toxin suppresses tumor growth through dual signaling pathways. Curr Mol Med. 2012; 12:1350-60. 